\title{
0 Conceito de Federalismo e a Idéia de Interesse no Brasil do Século XIX*
}

Ivo Coser

W este artigo, o objetivo é abordar o conceito de federalismo e a conceito de federalismo deve ser pensado de forma conjunta com o tema do interesse. Busco assinalar as mudanças sofridas pelo conceito em momentos históricos fundamentais do século XIX. Usualmente a literatura discute o debate entre centralização e federalismo sem perceber as descontinuidades, no âmbito político, que acometeram o conceito ao longo do século XIX ${ }^{1}$. Efetuo uma análise dos momentos históricos nos quais estiveram em discussão propostas que descentralizavam a organização do poder a fim de perceber as alterações na idéia de federalismo.

A análise dos debates parlamentares ocorridos na Constituinte de 1823 apontam para o fato de que o termo federalismo era entendido como confederação, ou seja, a reunião de Estados soberanos em torno de um centro comum. Essa maneira de organizar o Estado era entendida como compatível com a monarquia. Ao longo desses debates, emerge com clareza a idéia de que a província deveria dispor dos meios neces-

\footnotetext{
* Este artigo reúne aspectos discutidos em minha tese de doutorado defendida no Instituto Universitário de Pesquisas do Rio de Janeiro - IUPERJ em dezembro de 2006, intitulada O Pensamento Político do Visconde do Uruguai e o Debate entre Centralização e Federalismo no Brasil (1822-1860), lançada posteriormente como livro pela editora da Universidade Federal de Minas Gerais - UFMG/IUPERJ em 2008.
}

DADOS - Revista de Ciências Sociais, Rio de Janeiro, Vol. 51, nº 4, 2008, pp. 941 a 981. 
sários para gerir sua justiça e economia internas. O desenvolvimento e a eficácia da justiça somente seriam obtidos caso a província dispusesse de autonomia.

O pensamento federalista articulado em torno do Código do Processo (1832) entende que a descentralização deve permitir que o cidadão situado no município participe da montagem do aparelho judiciário. Nesse contexto histórico, o tema da participação do cidadão ativo e a educação política que aquela propicia são os valores principais mobilizados pelos federalistas. $\mathrm{O}$ conceito ${ }^{2}$ de federalismo passa a estar relacionado aos valores associados à participação do cidadão ativo na esfera que lhe é mais próxima, ou seja, o município. Nessa esfera, o cidadão poderia articular seus interesses particulares com a produção do bem público.

As revoltas regenciais levam o pensamento federalista a reformular essa perspectiva, concedendo precedência ao tema do interesse provincial. Os debates em torno do Ato Adicional (1831-1834) apontam para uma revisão do projeto federalista. A partir da análise de debates parlamentares e de jornais da época, considero que a idéia de interesse provincial emerge como um aspecto central do conceito de federalismo.

\section{A DEFINIÇÃO CONTEMPORÂNEA DE FEDERALISMO}

A definição contemporânea de federalismo o apresenta como um sistema de governo no qual o poder é dividido entre o governo central (a União) e os governos regionais. O federalismo é definido, em sua acepção positiva, como um meio-termo entre um governo unitário, com os poderes exclusivamente concentrados na União, e uma confederação, na qual o poder central seria nulo ou fraco. Por sua vez, a confederação é caracterizada como uma aliança entre Estados independentes. O governo central não poderia aplicar as leis sobre os cidadãos sem a aprovação dos Estados, que seriam, em última instância, a fonte da soberania. A diferença essencial entre federação e confederação é que, na primeira, o governo central possui poder sobre os cidadãos dos Estados ou províncias que compõem a União sem que essa ação tenha de ser acordada pelos Estados ${ }^{3}$. A experiência histórica que gera esse novo conteúdo é a construção do Estado norte-americano a partir de 1787.

A Convenção da Filadélfia foi convocada em 1787 com o intuito de rever os artigos aprovados no Congresso Continental em 1777 (usualmente conhecidos como Artigos da Confederação) $)^{4}$. Observemos, ini- 
cialmente, que aspecto Hamilton, no artigo 15, criticava na confederação norte-americana produzida em 1777:

O vício enorme e radical na construção da Confederação atual está no princípio da legislação para Estados ou governos em seu caráter de corporações ou coletividades, em contraposição à legislação para os indivíduos que os compõem. Embora não se estenda a todos os poderes conferidos à União, esse princípio invade e governa aqueles de que depende a eficácia dos demais. Exceto no tocante à honra de rateio, os Estados Unidos têm direito ilimitado a requisitar homens e dinheiro; mas não têm autoridade para mobilizá-los por meio de normas que se estendam aos cidadãos da América. A conseqüência é que, embora em teoria as resoluções da União referentes a essas questões sejam leis que se aplicam constitucionalmente aos seus membros, na prática elas são meras recomendações que os Estados podem escolher observar ou desconsiderar (Madison, Hamilton e Jay, 1993:160-161).

É fundamental que assinalemos com ênfase o principal defeito, para Hamilton, da confederação elaborada em 1777: o poder central não dispunha de autonomia para agir sobre os cidadãos que compunham a União. Poderia apenas recomendar a aplicação de suas resoluções, cabendo aos Estados adotar ou não tais resoluções. A solução política, para o autor, consistia no reforço do poder central. Este deveria dispor dos poderes necessários para agir sobre os cidadãos, sem passar pelos Estados. A conseqüência desse reforço seria uma alteração fundamental no status constitucional dos Estados, que deveriam dispor de autonomia, mas não seriam mais entidades soberanas; agora estariam subordinados ao poder central.

Podemos perceber claramente a nova direção que Hamilton pretendia introduzir no arranjo constitucional norte-americano. Entretanto, para se referir às inovações que deveriam ser introduzidas, o autor ainda fazia uso do termo confederação. Vejamos um trecho do mesmo artigo 15 citado anteriormente:

Com o abandono de todas as pretensões a um governo confederado, isso nos reduziria a uma simples aliança ofensiva e defensiva e nos poria em condições de sermos ciclicamente amigos e inimigos uns dos outros, ao sabor de nossas cobiças e rivalidades. Mas se não queremos ser postos nessa situação; e se ainda nos mantemos fiéis ao projeto de um governo nacional, o que é a mesma coisa, de um poder superintendente sob a direção de um conselho comum, devemos incorporar em nosso 
plano aqueles ingredientes que podem ser considerados pela diferença entre uma liga e um governo; devemos ampliar a autoridade da União às pessoas dos cidadãos - os únicos objetos próprios de governo ( $i b i$ dem:161-162).

Observemos que Hamilton condenava o fato de que fossem abandonadas todas as pretensões a um governo confederado em detrimento de uma mera liga. Esta seria, segundo ele, a mera reunião de Estados, uma aliança com fins defensivos ou ofensivos. Para Hamilton, deveriam ser introduzidas inovações que estabelecessem uma diferença radical entre uma confederação (confederate government) e uma liga (league). Para tanto, o autor argumentava que seria imprescindível que a União tivesse os poderes necessários para chegar até o cidadão.

Podemos assinalar que Hamilton já mencionava um de seus elementos distintivos, ou seja, a capacidade de o governo central chegar até os cidadãos das unidades que compõem o Estado sem passar pelo crivo dessas unidades. Ocorre que o político norte-americano faz uso do termo governo confederado, distinguindo esse novo arranjo político de uma mera liga sem fazer a distinção entre federação e confederação, como seria mais usual em nossa contemporaneidade. Revela, dessa forma, que sob uma palavra antiga se manifestava um novo conteúdo. $\mathrm{O}$ uso do termo confederação de Estados para se referir aos Estados Unidos da América foi comum até a Guerra Civil (1861-1865) ${ }^{5}$. Esse descompasso entre o novo conteúdo histórico, gerado a partir da experiência norte-americana, e a persistência de velhas palavras foi claramente percebido por Tocqueville (1977:123):

Em todas as confederações que precederam a União Americana de nossos dias, o governo federal, a fim de prover às suas necessidades, dirigia-se aos governos particulares. No caso em que a medida prescrita desagradava a um deles, este podia sempre subtrair-se à necessidade de obedecer. [...] Na América, a União tem por governados, não Estados, mas simples cidadãos. Quando quer cobrar um imposto não se dirige ao governo de Massachusetts, mas a cada um habitante de Massachusetts. Os antigos governos federais tinham diante de si povos; o da União tem indivíduos. Não toma emprestada a sua força, mas vai ele mesmo buscá-la. Tem seus próprios administradores, seus tribunais, seus oficiais da justiça, seu exército. [...] Aqui o poder central age sem intermediários sobre os governados, julga-os ele próprio, como fazem os governos nacionais, mas só age, neste caso, dentro de um círculo restrito. [...] Assim, achou-se uma forma de governo que não era, precisa- 
mente, nem nacional, nem federal; mas parou-se aí, e a nova palavra que deve exprimir a coisa nova de maneira alguma existe ainda ${ }^{6}$.

Em Tocqueville está presente a percepção da inovação da Convenção da Filadélfia para com as experiências européias de confederação, ou seja, a União atuava diretamente sobre os cidadãos, sem a necessidade de recorrer às unidades da federação. Entretanto, essa centralidade da União não era semelhante àquela dos Estados unitários, pois as unidades que compunham o Estado dispunham de uma autonomia e de liberdades que inexistiam nos Estados unitários. Nestes, as partes que compunham o Estado eram meramente unidades administrativas, sem dispor de autonomia e de liberdade para escolha de funcionários, organização da Justiça e recolhimento de impostos, aspectos que ocorriam no caso norte-americano.

O autor francês lamentava que não houvesse um termo novo capaz de designar o arranjo norte-americano. Nesse sentido, Tocqueville assinalava o descompasso entre as palavras disponíveis (federação e confederação) e a novidade histórica. Ao longo do debate político anterior, federação havia sido um sinônimo de confederação. Quando, posteriormente, o termo foi associado exclusivamente à novidade introduzida pelo caso norte-americano, o que ocorreu foi meramente a reutilização de um antigo termo para um novo conteúdo.

Portanto, podemos observar os seguintes pontos: 1) o uso dos termos federação e confederação para se referir ao caso norte-americano era um procedimento comum. Isso porque a palavra federação estava associada à confederação. 2) A inovação produzida pela experiência norte-americana consistiu no seguinte conteúdo: as unidades que compunham a União disporiam de autonomia política e administrativa, entretanto, isso não implicava um poder central fraco ou nulo; os Estados não seriam entendidos como um poder soberano tal qual a União. As resoluções da União teriam caráter impositivo para os Estados, e não mais seriam meras recomendações. Ao mesmo tempo que o poder central era reforçado, os Estados disporiam de autonomia decisória em aspectos importantes. Nesse sentido, a idéia de federação era uma novidade política, como bem escreveu Tocqueville; não era uma repetição das confederações, pois o poder central era forte, tampouco os estados desempenhavam o mesmo papel que em um Estado unitário. 


\title{
O CONCEITO DE CONFEDERAÇÃO/FEDERALISMO NO DEBATE POLÍTICO BRASILEIRO NA CONSTITUINTE DE 1823
}

Logo no começo dos debates parlamentares da Constituinte de 1823, entrou em discussão uma emenda estabelecendo que o Império brasileiro compreendesse confederalmente as províncias que formavam o antigo Império português na América ${ }^{7}$. Ao longo dos debates, e não apenas dessa emenda, os deputados utilizavam indistintamente os termos federação e confederação. Em que pese o uso indistinto, ocorreu a predominância do conteúdo proveniente da experiência confederativa; as inovações norte-americanas ainda não haviam sido incorporadas ao debate brasileiro. O termo confederação/federação é definido como a reunião de Estados soberanos com o objetivo de resistir a ameaças externas. Nesse modelo, o poder da União é fraco ou mesmo nulo, dependendo, para sua ação, de recursos e de autorização dos Estados-membros:

\begin{abstract}
É bem conhecida a confederação Helvetica, a dos antigos estados geraes da Holanda, quando este se constituiu em república, e a confederação do corpo germânico composta de estados independentes, ainda que associados para a resistência a inimigos comuns, contribuindo cada estado com seu contingente de soldados e dinheiro para as despesas gerais de sua associação, até sendo cada estado regido por sua particular forma de governo (Silva Lisboa, sessão da Câmara dos Deputados, 17 de setembro de 1823, p. 158; ênfase do autor).
\end{abstract}

Essa definição não implicava uma incompatibilidade entre a forma de governo monárquica e o modelo confederativo/federalista. O deputado Carneiro Cunha expressava uma opinião bastante difundida na Constituinte: "[...] federação não se opõe à monarquia constitucional, como há exemplos, tanto na história antiga como na moderna, e mesmo na Europa [...]" (Assembléia Constituinte, 17 de setembro de 1823, p. 152). A definição de confederação/federação acarretava, para as correntes federalistas, três pontos: 1) o rompimento do pacto colonial implicava o retorno do poder soberano para as diversas províncias; 2) o pacto a ser firmado na Constituinte deveria retornar às províncias para sua aprovação ou recusa; 3) o arranjo constitucional deveria conferir autonomia às províncias ${ }^{8}$. Na elaboração desse último aspecto, as correntes federalistas buscaram afirmar a precedência da província. Na medida em que a província possuía precedência diante da União, 
os poderes escolhidos nesta deveriam dispor de autoridade e de autonomia:

Que as províncias são ajuntamentos de homens com iguais direitos. Que neste exercício de direitos iguais e maneiras de maior utilidade se funda a união federal de homens, casas, vilas, cidades, províncias e reinos, sujeitando-se todos ao Império de um, a quem tributão mantença e honra para salvação certa de todos, ajuntando-se os seus procuradores em concílio comum, para se estabelecerem as regras da prol geral, ficando a prol de cada casa a indagação mais perspicaz e interessada dos filhos (Ferreira França, sessão da Câmara dos Deputados, 18 de setembro de 1823, p. 130; ênfase do autor).

[...] federação não se opõe à monarquia constitucional, como há exemplos, tanto na história antiga, como na moderna, e mesmo na Europa, [...]; podendo haver em cada uma das províncias uma primeira assembléia provincial, que tenha a iniciativa das leis regulamentares, e que informando com mais conhecimentos à assembléia dos representantes da nação tudo quanto for mister para promover a sua prosperidade, consiga-se desta sorte o bem, que todos desejamos. Considerada, e admitida por esta forma, a federação opor-se-á à integridade do Império? Não, decerto" (Carneiro Cunha, Assembléia Constituinte, 17 de setembro de 1823, pp. 152-153; ênfase do autor).

Para a corrente federalista, a forma de governo monárquica representativa deveria permitir que cada província buscasse a realização de seus interesses conforme cada qual os entendesse. Esse é um limite legitimamente reconhecido pelas partes quando realizam o pacto. A submissão ao monarca ocorria tendo em vista a liberdade das províncias em promoverem sua prosperidade. Essa busca implicava dois aspectos: a existência de um Legislativo provincial que dispusesse de autonomia em face do legislativo nacional e que a escolha ou a eleição dos funcionários fosse feita a partir dos cidadãos ativos residentes na província e pelos poderes provinciais. Tal procedimento encontrava justificativa nos motivos do comportamento do funcionário oriundo da província: vínculos para com a localidade. Esses funcionários estariam diretamente empenhados em contribuir para a prosperidade local. Podemos assinalar, no argumento federalista acerca do funcionário, a presença da idéia de interesse, ou seja, velar pelo que é seu ${ }^{9}$. O funcionário local seria mais eficiente do que um funcionário sem vínculos nomeado pelo poder central. Para os federalistas, o bom desempenho do funcionário não provém de seu treinamento nem de seu vínculo com o po- 
der central, mas de sua ligação com a localidade. Na medida em que, por meio desse funcionário, estão presentes os objetivos da província, ele é superior a um funcionário mais treinado e vinculado a interesses que não estão referidos à dinâmica provincial.

Devemos enfatizar o seguinte aspecto: a forma de governo é um fator secundário neste debate. Observemos que, para Ferreira França, o que é relevante é que esteja garantido que cada província disponha de liberdade para administrar seus interesses, para governar a casa. Desde que esse dado esteja garantido, não há nenhum problema que a forma de governo seja a monárquica. A província somente entraria no pacto se ficasse assegurado que caberia a ela a administração da casa.

O uso da idéia da casa no argumento federalista nos remete à análise de Ilmar Rohloff de Mattos sobre o Império brasileiro. Ele elabora o conceito de casa como um dos instrumentos fundamentais para a interpretação das idéias dos liberais moderados no Império (1994:109-123). Segundo esse autor, a dimensão da casa envolvia a esfera privada; o responsável pela casa era o encarregado de regular a economia e sua administração, cuidando da família, dos agregados e dos escravos. Os liberais moderados projetavam para o Estado essa dimensão. Nessa projeção, ganhava proeminência o chefe da casa, que desempenhava o papel ativo em sua administração.

No argumento federalista, a província desempenharia o mesmo papel do indivíduo com relação à sua casa; o indivíduo tem interesse em buscar a prosperidade e a felicidade de sua casa. Nesse sentido, a província deve controlar as atividades que dizem respeito à realização de seus interesses. Os federalistas transpõem uma idéia proveniente da esfera privada para a esfera pública: administrar o Estado da mesma maneira que o cidadão ativo vela por sua casa.

Portanto, podemos delinear o seguinte conteúdo na idéia de federação: o Estado é mais bem administrado quando os interesses provinciais estão em primeiro plano. Para a corrente federalista, as províncias deveriam dispor do controle sobre a segurança, a administração e a prosperidade material. A dimensão privada se projeta sobre a esfera pública não em sua dimensão patrimonial, mas como a precedência do interesse provincial como a mola fundamental na montagem do Estado. 
Ainda que na Constituinte de 1823 já esteja presente a idéia de que, no modelo federativo, a província vela por seus assuntos com a mesma acuidade que o cidadão ativo cuida de sua casa, essa temática emergirá com mais intensidade nos debates em torno do juiz de paz (1827) e do Código do Processo (1832). O debate político acerca dessas duas leis revelou uma dimensão relevante para a compreensão do conceito de federalismo.

\section{O CÓDIGO DO PROCESSO: O FEDERALISMO COMO A DISSEMINAÇÃO DO PODER PELA SOCIEDADE}

Com a abdicação de D. Pedro I ocorreram mudanças significativas na composição social da elite política hegemônica. O período regencial foi marcado pela ascensão do setor social ligado ao abastecimento interno no sul de Minas Gerais. Segundo Lenharo (1993), o setor mercantil de abastecimento desempenhou um papel importante na economia brasileira até a década de 1830, quando o café se tornou a principal atividade e o setor foi disputado por dois grupos. O primeiro, localizado sobretudo no sul de Minas Gerais, também incluía paulistas e fluminenses. Suas atividades estavam relacionadas à produção mercantil de subsistência e de exportação. Já o segundo procedia da Corte e fora recrutado principalmente entre a nobreza e a alta burocracia de Estado. Sua criação foi fruto de uma política generosa de D. João VI e de D. Pedro I, que distribuíram vastas extensões de terra nas proximidades do Rio de Janeiro. O primeiro grupo apresentava força política no âmbito provincial, mas era barrado na Corte pelo segundo grupo, que se valia de sua maior proximidade com o novo monarca (ver Lenharo, 1993:24). Em 1831, com a abdicação do imperador, o primeiro grupo passa a controlar o processo político. O segundo, com os recursos do setor de subsistência, financia a colonização e a expansão da economia cafeeira no Vale do Paraíba, vindo a dar o troco durante o regresso conservador.

Na Constituinte de 1823, predominou a compreensão do federalismo como uma dimensão que dizia respeito exclusivamente à organização das províncias. A análise acerca do debate em torno da lei do juiz de paz e do Código do Processo nos revelou que o conceito de federalismo foi ampliado de sua dimensão inicial. $O$ federalismo não estava relacionado apenas à descentralização do poder no âmbito provincial; a descentralização do poder deveria ser disseminada sobretudo pela sociedade, a fim de que o cidadão ativo situado nos municípios partici- 
passe diretamente, ou por meio dos órgãos municipais, da montagem do Estado.

Com a elaboração do Código do Processo Criminal, parte substancial dos encarregados da justiça criminal passou a ser eleita no município. $\mathrm{O}$ Código do Processo aumentou consideravelmente tanto os poderes do juiz de paz, tornando-o o principal agente do Judiciário nas localidades, quanto os do júri, além de estabelecer que o promotor e o juiz municipal seriam escolhidos no município.

De acordo com a Lei de 1827, o juiz de paz era eleito diretamente pelos cidadãos da localidade, sendo, portanto, uma expressão da vontade política destes. É importante destacar algumas características dessa eleição: direta e única, sem intermediários entre o eleitor e a figura do representante, ou seja, expressão direta das vontades do eleitorado. Observemos os motivos pelos quais o juiz de paz ganhou essa importância: em primeiro lugar, pela extinção do delegado; em segundo, porque ficou encarregado de elaborar o auto do processo criminal ${ }^{10}$.

No art. 19, o Código do Processo aboliu os delegados, que antes eram nomeados pelo poder central e ficavam subordinados ao chefe de polícia, que também possuía a mesma origem. Na medida em que não havia mais os delegados, as ações do chefe de polícia nos municípios passavam a depender do juiz de paz, o qual ficava encarregado de recrutar a Guarda Nacional para cumprir ordens judiciais, mandados de busca etc. Nesse sentido, as ações do poder central passavam a depender da cooperação de uma figura eleita na localidade.

Com o Código do Processo, o juiz de paz era quem procedia ao corpo de delito, que vem a ser "o conjunto de elementos sensíveis do fato criminoso" (Almeida Júnior, 1920:7), e formava a culpa (ver Código do Processo, art. 12, § 4); esta era então entregue ao juiz de direito e ao júri de acusação para que deliberassem se existia a necessidade de se instaurar um processo (ver Código do Processo, art. 228). Em caso positivo, iniciava-se o julgamento a partir das provas recolhidas anteriormente.

Para que o juiz de direito declare a responsabilidade criminal e imponha a sanção, é necessário ter certeza de que um ilícito penal foi praticado e de que é possível identificar seu autor (cf. Almeida Júnior, 1920). No Estado moderno, a única maneira pela qual um juiz pode ser convencido a emitir um julgamento é por meio das provas, que devem ser obtidas mediante certas formalidades marcadas constitucional- 
mente (ver Bajer, 2002). Além desse importante papel no processo criminal, o juiz de paz julgava pequenos delitos e concedia o passaporte para o deslocamento interno (ver Código do Processo, art. 12, §§ 1-7).

No Código do Processo, além do juiz de paz, havia três importantes figuras que eram escolhidas entre os cidadãos da localidade: o promotor, $\mathrm{o}$ juiz municipal e o júri popular. Segundo esse Código, o promotor ficava encarregado da denúncia de crimes públicos e policiais perante o júri, sendo escolhido pelo presidente de província a partir de uma lista tríplice elaborada pela Câmara Municipal entre os eleitores locais. Qualquer eleitor com bom senso e probidade reconhecidos poderia compor a lista; a lei, ademais, mandava que se desse preferência aos que fossem instruídos nas leis (ver Código do Processo, art. 36). O juiz municipal ficava encarregado de substituir eventualmente o juiz de direito e de exercer cumulativamente a jurisdição criminal. Era escolhido da mesma forma e com os mesmos pré-requisitos que o promotor (ver Código do Processo, art. 33). Já a lei do júri popular foi promulgada em setembro de 1830 em meio ao processo de dissídio entre o imperador, D. Pedro I, e a elite política brasileira, nesse momento ainda toda unida contra as ações daquele. No art. 15, a lei determinava que o júri fosse escolhido pelos eleitores da municipalidade e pelos vereadores. Com a promulgação do Código do Processo Criminal, em 1832, essa escolha passa a ser feita pelo juiz de paz, pelo capelão e pelo presidente da Câmara Municipal (ver Lei da Eleição dos Jurados e Promotores, art. 15, e Código do Processo Criminal, art. 24). Podiam ser jurados todos aqueles que fossem eleitores de segundo grau; para aferir se havia algo contra eles, seus nomes eram publicados. Findas as contestações, se porventura houvesse, as urnas com os nomes eram lacradas para que fossem sorteados na época dos julgamentos. Portanto, figuras importantes do funcionamento da Justiça (juiz de paz, promotor, júri e juiz municipal) passaram a ser escolhidas ou eleitas a partir do município.

Essa característica levou a uma série de artigos publicados no jornal Astro de Minas, assinados por Do Federalista, nos quais o aspecto positivo do modelo federalista era a responsabilidade que o funcionário eleito possuía perante os cidadãos ${ }^{11}$. Esse jornal era ligado aos liberais moderados. Nova Luz Brasileira, ligado aos liberais exaltados, argumentava que a federação acarretaria a eleição de todo o poder Judiciário (ver Nova Luz Brasileira, 7/1/1831) e dos comandantes de armas (ver Nova Luz Brasileira, 4/1/1831). 
A idéia de federação chega ao Brasil enfatizando a necessidade de que as atribuições do poder central sejam deslocadas para a província. No entanto, esse movimento de retirar as atribuições do poder central não fica restrito a uma transferência destas para as assembléias provinciais; chega até os municípios. No debate político brasileiro, a idéia de federalismo esteve diretamente associada a um movimento no qual o exercício do poder público é espalhado na sociedade. Em outras palavras, é posto ao alcance do cidadão ativo.

Nesse momento histórico, parte considerável dos federalistas acreditava que o federalismo permitiria que os interesses dos cidadãos ativos e a liberdade caminhassem de maneira virtuosa. Um dos mais importantes era Evaristo da Veiga ${ }^{12}$, que em 1833 - o ano seguinte à promulgação do Código - escreveu acerca da importância da eleição do juiz de paz:

O dia das eleições se avizinha, e tenho de contribuir com meu voto para a nomeação dos juízes de paz do meu distrito. N'outro tempo, eu nada entendia da influencia que podia ter hum bom ou mau juiz de paz; deixava a escolha ao acaso, persuadido que de todo modo as coisas hirião bem [...]. Mas depois de 7 de abril, quando começarão a correr pelas ruas magotes de gente armados de facas, grande número de ociosos, de vagabundos [...] que assustavam o povo, ameaçando os bens e a vida de cada um. [...]. Duraram os sustos alguns meses: mas homens de bem exerciam o cargo de juiz de paz, eles animaram os cidadãos e reprimiram os perturbadores [...]. Aprendi então a conhecer a importância daquele emprego e prometi ter grande escrúpulo no meu voto toda vez que se tratasse de eleger juízes de paz. [...]. Contaram-me huma vez que se trabalhava para nomear eleitores a certos sujeitos que não mereciam conceito, que para este fim havia um ajuste, ou como eles dizem - huma cabala; e me convidarão a ligar-me com outros cidadãos que pretendiam votar em pessoas de mais estimação e confiança. Imbuído como estava das minhas idéias, respondi que não entrava em conluios. Outros foram da mesma opinião, e a cabala que eu receava triunfou completamente. Então eu reconheci que em eleições é necessário ceder do próprio juízo, de particulares afeições, de relações de comércio ou de família, e encostar-se o votante àquele círculo que melhor lhe agrada, que está mais de acordo com seus desejos e esperanças (Aurora Fluminense, 15/2/1833; ênfase no original).

Observemos que, para Evaristo, o eleitor é despertado para a importância da eleição de juiz de paz quando desordeiros ameaçaram sua 
propriedade. O cidadão movido pelo interesse de que a lei garanta sua esfera privada não deve permitir que um funcionário nomeado por um poder distante tenha influência sobre seus assuntos. Quando ocorrem as primeiras eleições, esses cidadãos, pouco habituados ao exercício do poder em sua esfera mais próxima, não se envolvem. Séculos de uma legislação colonial opressiva não lhes ensinou a se envolver com os assuntos públicos. No entanto, quando fatos que põem em risco seus interesses ocorrem, esses eleitores decidem participar. Evaristo não se ilude acerca da capacidade da lei em mudar os costumes arraigados; reconhece que não será imediatamente que os cidadãos ativos sairão de seu isolamento. Segundo Evaristo, nas primeiras eleições, as cabalas vencem. O motivo reside no fato de os cidadãos ainda não terem saído de sua esfera privada. Apenas lentamente, mediante o exercício da participação, o cidadão ativo vai escolher melhor o juiz de paz. O cidadão associará seus interesses individuais - a proteção de sua propriedade - à escolha de funcionários públicos que respeitem seus direitos. Reconhecerá que, para que tal escolha recaia sobre um candidato correto, deve haver um envolvimento com outros eleitores.

Essa ação coletiva somente pode ocorrer quando existe a liberdade de escolha, a eleição de um magistrado, por exemplo, na qual diversos candidatos participam; muitos desses candidatos são homens que se impõem não por seu cabedal pessoal - estudos e propriedades -, mas sim em razão da alta estima de seus concidadãos. Essa participação só ocorre porque o funcionário eleito responde perante os demais cidadãos ativos.

Cabe pôr em destaque o sentido que o conceito de federalismo recebe nesse momento histórico. Em primeiro lugar, o arranjo constitucional federalista é definido a partir de dois pontos: o mecanismo de responsabilidade que os funcionários possuem para com os cidadãos - seja na esfera provincial, seja na esfera municipal - e a liberdade de que as províncias devem dispor para administrar seus recursos e legislar tendo em vista suas realidades singulares. Em segundo lugar, e diretamente associado ao primeiro, esse modelo constitucional permite que o cidadão olhe para o que é público como algo que lhe diz respeito, e não como algo que somente diz respeito a um funcionário nomeado por um poder distante. O cidadão exerce seu interesse individual junto ao interesse público. Essa característica do pensamento federalista formulado em torno do Código do Processo pode ser percebida por meio do conceito de interesse bem compreendido formulado a partir da leitura da 
obra de Tocqueville (1977). Na análise que o autor efetuava da experiência norte-americana, estava presente a idéia de que nos Estados Unidos o interesse individual, longe de colocar o cidadão em uma prisão, isolado dos demais, era capaz de ligá-lo a outros. Para Tocqueville, o cidadão norte-americano, ao efetuar uma ação tendo seu interesse privado como móvel, terminava produzindo uma ação dotada de virtudes públicas.

Seguindo as lições de Montesquieu, Tocqueville considerava que às instituições deve corresponder um espírito que as anime. Nesse sentido, o autor enxergou na experiência norte-americana cidadãos comuns, movidos por seus interesses individuais, envolvidos nas soluções de problemas coletivos, unindo sua liberdade com a liberdade pública. O interesse do indivíduo por suas coisas, bem como o apego ao que lhe pertence, consegue se tornar uma virtude. A dispersão do poder na sociedade norte-americana leva o indivíduo, na defesa de seu interesse, a sair do isolamento e a buscar a cooperação de outros na procura de soluções (cf. Jasmin, 2000:77).

O "patriotismo municipal" (expressão de Tocqueville apud Jasmin, 2000) norte-americano é o espaço institucional primordial para a manifestação do interesse bem compreendido. Sem este os cidadãos jamais obterão o aprendizado prático para a resolução dos assuntos públicos, tampouco associarão corretamente sua liberdade individual à liberdade pública. Os Estados centralizados, equivocadamente, somente chamam seus cidadãos para decidir os assuntos gerais, abstratos, sem uma ligação direta e imediata com a vida desses indivíduos.

É importante assinalar que, para Tocqueville, o interesse bem compreendido se manifesta sem nenhuma referência a uma virtude heróica externa aos interesses dos cidadãos; está relacionado apenas ao empenho do indivíduo em resolver seus problemas. A partir dessa paixão pouco nobre, o cidadão supera seu isolamento, constrói uma esfera pública baseada na liberdade e internaliza a lei como expressão do bem público (Werneck Vianna, 1997:109).

A Regência marca a entrada no núcleo do poder de um grupo que não participava do poder na época de D. Pedro I. A referência a Tocqueville nos permite compreender o mecanismo que os defensores do Código do Processo pretendiam pôr em movimento. A idéia de federalismo formulada durante o Código reforça a idéia de desconfiança para com o Estado. A única maneira de assegurar os interesses e a liberdade dos ci- 
dadãos seria tornar os cargos públicos mais importantes eleitos ou escolhidos a partir dos municípios. Torna-se fundamental compreender que os federalistas descrevem a eleição do juiz de paz e a escolha dos demais cargos pelos poderes municipais como um espaço no qual os cidadãos, movidos por seus interesses, criam um vínculo positivo com o Estado e com a liberdade pública. Somente no modelo institucional em que o poder público esteja sujeito aos interesses dos cidadãos, estes podem internalizar a Lei. $O$ federalismo era o arranjo político que permitiria a combinação entre virtude e interesse de maneira satisfatória.

O pensamento federalista não desconhecia a demora para que essas práticas vingassem na sociedade brasileira. Nesse sentido, veja um trecho do jornal Astro de Minas:

Nós não desconhecemos que o sistema federativo no Brasil há de acarretar alguns inconvenientes; sobretudo no princípio. [...] mas ousamos asseverar, que para as futuras eleições os Povos já amestrados pelos poucos prejuízos não votarão em semelhantes carrascos, e assim pouco a pouco irão abrindo os olhos acerca da escolha dos candidatos. [...]. Mas formada que esteja a federação de Estados fazendo as suas leis próprias e peculiares, tendo em seu seio todos os recursos, só por isso poderá empregar toda a força de que é capaz; as autoridades sempre vigiadas e prestes a responder pelos seus abusos estarão em contato com os povos que as elegerão (Do Federalista, Astro de Minas, 28/6/1832; ênfases do autor).

As alterações nas leis não implicariam mudanças imediatas na prática social. Entretanto, uma mudança somente ocorreria caso fosse dado aos cidadãos o espaço público para que seus interesses individuais fossem lentamente educados a fim de combinar interesses e bem público. Os federalistas brasileiros não tiveram a preocupação de compatibilizar esses interesses com uma virtude heróica, proveniente de uma nobreza que de maneira desinteressada velaria pela res publica. Seu mundo de origem e sua referência eram os homens comuns que, dispondo de propriedade e de interesses individuais, deveriam controlar um Estado. Este, em razão da experiência colonial e do reinado de D. Pedro I, surgia como uma ameaça a seus interesses. No entanto, para os federalistas, controlar o Estado a partir dos interesses era indissociável da descentralização do poder, de colocar o poder sob a influência dos cidadãos ativos e da esfera pública na qual estes tomavam parte e de tornar o poder sujeito à influência da opinião pública, dos pasquins, das sociedades, entre outros. 


\section{ATO ADICIONAL ${ }^{13}$ CONTRA O CÓDIGO DO PROCESSO}

O conceito de federalismo, discutido a partir da promulgação e do funcionamento do Código do Processo, sofre modificações relevantes para sua compreensão. Em primeiro lugar, grupos defensores do federalismo efetuam uma crítica à descentralização presente no Código do Processo; em segundo, a inovação da experiência norte-americana é percebida; em terceiro, conferem precedência ao interesse provincial em face do tema da liberdade. Essas alterações ganham corpo ao longo dos debates em torno do Ato Adicional.

O Ato Adicional possui um histórico que tem início em 6 de maio de 1831, quando o deputado Miranda Ribeiro apresentou e conseguiu a aprovação do requerimento que previa a formação de uma comissão para propor a reforma da Constituição. Em 9 de julho de 1831, a comissão formada por Paula e Souza, Miranda Ribeiro e Paraizo apresentava o resultado dos trabalhos. O momento político no qual se dá a proposta de Miranda Ribeiro era extremamente crítico. O imperador abdicara havia apenas dois meses; a Regência estava se assentando no poder; e a capital fora palco de várias revoltas, durante as quais se pensou em retirar o jovem imperador da cidade em virtude da inexistência de segurança para sua pessoa. A gravidade dos conflitos armados foi tamanha que impulsionou o projeto da Guarda Nacional. Proposto em julho de 1831, os pontos mais debatidos foram: o Senado temporário eleito pela Assembléia Provincial e a monarquia federativa.

No primeiro artigo, sem deixar dúvidas a que veio, o parecer da comissão propõe uma nova redação do art. 1o da Constituição: o Império do Brasil seria uma associação política dos cidadãos brasileiros de todas as suas províncias federadas por essa Constituição. Além da monarquia federativa, a comissão propõe a separação entre rendas provinciais e gerais, o que será mantido no Ato Adicional. O Senado deixaria de ser vitalício, escolhido pelo imperador a partir de uma lista tríplice, e passaria a ser eleito pela Assembléia Provincial. Esta também ficaria encarregada da eleição do vice-presidente. Por último, o projeto propõe a supressão do Poder Moderador e do Conselho de Estado ${ }^{14}$.

O Senado reconheceu a constitucionalidade da reforma, entretanto, transferiu sua realização para representantes eleitos para tal, ou seja, para a próxima legislatura, e negou a possibilidade de reforma dos artigos que tornavam a monarquia federativa e o Senado temporário e eleito a partir das Assembléias Provinciais ${ }^{15}$. A derrubada desses dois 
pontos - monarquia federativa e Senado temporário e eleito pelas Assembléias - pôs em marcha a tentativa de aprovar as reformas sem a participação do Senado. Um dos principais artífices desse movimento foi o ministro da Justiça, Diogo Feijó. A Constituição de Pouso Alegre, principal documento político desse movimento, incorporava os pontos do projeto apresentado pela comissão ${ }^{16}$.

Em 30 de julho de 1832, a Câmara se reúne para tentar votar um parecer segundo o qual ela se converteria em Assembléia Nacional para empreender a reforma mesmo sem a anuência do Senado. Durante os debates na Câmara dos Deputados, Honório Hermeto agrupou uma maioria capaz de derrotar esse movimento. A derrota aponta para um reconhecimento, por parte dos descentralizadores, dos limites impostos pelo Senado. Nesse sentido, forma-se, na Câmara, uma nova comissão composta por Bernardo Pereira de Vasconcelos, Limpo de Abreu e Paula de Araújo. As linhas centrais do projeto elaborado por essa comissão formarão a base do Ato Adicional aprovado em 1834.

Logo após a promulgação do Ato Adicional, Alves Branco e Limpo de Abreu, dois importantes defensores do Ato Adicional e críticos do regresso conservador, efetuaram crítica ao Código do Processo em bases semelhantes. O Código do Processo transferiu atribuições para cidadãos que, apesar de seus vínculos para com a localidade, não possuíam preparo técnico para o desempenho das pesadas funções que lhes foram delegadas ${ }^{17}$. As leis descentralizadas são um instrumento por meio do qual os cidadãos ativos se civilizam ${ }^{18}$; porém, esses mecanismos deveriam ser aplicados apenas em regiões com um determinado nível de desenvolvimento ${ }^{19}$. Com o Ato Adicional promulgado em 1834, a aplicação dos mecanismos descentralizadores presentes no Código do Processo passou a ser controlada pelo Legislativo provincial. Esse espírito presente no Ato Adicional foi claramente percebido por Tavares Bastos. Segundo este, não bastava escrever que todos os cargos do Judiciário seriam eletivos; o nível de civilização existente no país não permitia que esse mecanismo fosse aplicado indistintamente, apenas o Legislativo provincial poderia decidir como e onde essa legislação poderia ser aplicada (ver Bastos, 1937, parte II, cap. IV:162-163; 173). A inexistência de um determinado nível de civilização ${ }^{20}$ homogeneamente difundido na sociedade brasileira apontava para a possibilidade de que os conflitos políticos transbordassem para além dos limites toleráveis para a elite política brasileira do século XIX. Vejamos alguns exem- 
plos mencionados no debate político do século XIX dessa função desempenhada pelo Legislativo provincial.

Em 1836, a Assembléia Provincial de Pernambuco retirou as atribuições policiais do juiz de paz, passando-as para os prefeitos e subprefeitos nomeados pelo presidente provincial (ver Bastos, 1937:169 e Souza, 1997). Em 1838, o Legislativo provincial de Alagoas atribuiu cumulativamente aos juízes municipais o exercício das atribuições criminais do juiz de paz (Bastos, 1937:169-170). A Assembléia Provincial de Alagoas determinou a elevação do censo para a seleção do júri e criou a figura dos prefeitos, nomeados pelo presidente provincial. A concessão de fianças seria uma atribuição delegada sobretudo ao juiz de direito, e não ao juiz de paz. Em 1835, a Assembléia Provincial de São Paulo criou a figura do prefeito nomeado pelo presidente de província. Este ficaria encarregado de fiscalizar os empregados municipais, comandar a Guarda Policial, prender os delinqüentes e vigiar as pessoas que entrassem no município (ibidem:169). Ou seja, incorporava diversas tarefas que cabiam ao juiz de paz.

Gostaria de chamar a atenção do leitor para o seguinte: esse conjunto de atos dos Legislativos Provinciais somente foram desencadeados em razão do Ato Adicional. De acordo com aqueles, as Assembléias Provinciais poderiam legislar sobre os funcionários provinciais, bem como sobre a divisão civil e judiciária. Os atos do Legislativo provincial atacavam as atribuições dos cargos eleitos ou escolhidos a partir do município (o juiz de paz, o júri e o promotor) em favor do juiz de direito e dos prefeitos. Como Tavares Bastos assinalava: "Conforme já advertimos quanto à polícia, o que as leis fortificavam era o juiz de direito ou juiz municipal" (1937:193). Em outras palavras, o Ato Adicional realizava a mesma tarefa do regresso conservador, ou seja, o esvaziamento dos cargos eletivos em detrimento dos cargos nomeados. No entanto, com uma diferença fundamental e chave: quem realizava essa tarefa era o Legislativo provincial, tendo em conta os interesses provinciais, $\mathrm{e}$ não os motivos do poder central. Além disso, com o Ato Adicional os cargos nomeados eram controlados pelo Legislativo provincial. O pensamento federalista procura deslocar a primazia política para o Legislativo provincial como um meio pelo qual seriam podados os excessos descentralizadores presentes no Código do Processo. A partir dos mecanismos presentes no Ato Adicional, os diversos legislativos provinciais iniciaram a reforma do Código do Processo, desmobilizando a participação dos cidadãos ativos exercida diretamente no município. 
A bibliografia tem usualmente creditado aos conservadores, a partir do fim dos anos 1830, a revisão da legislação descentralizadora. Essa compreensão considera o Ato Adicional um desdobramento natural das idéias federalistas presentes no Código do Processo. Em minha compreensão, essa visão implica reforçar a idéia de que os federalistas não tentaram conter a eclosão do "Brasil profundo", pois estavam imbuídos de um liberalismo utópico.

Neste artigo, a perspectiva é distinta: os liberais moderados recusam o encontro com as demandas das classes subalternas por terra e vão buscar a reforma do Estado imperial por dentro; a reforma do Estado seria a obra das elites provinciais ${ }^{21}$. A descentralização do poder, efetuada com o Código do Processo, forçou o "encontro das elites locais com a massa do povo sem direitos" (Werneck Vianna, 1991:158). O pensamento federalista, com sua idéia de tornar o poder responsável perante os cidadãos, recuou diante dos efeitos inesperados dessa opinião. A idéia de mobilizar a sociedade a partir do interesse bem compreendido, capturar o Estado e implementar a ordem e a justiça sucumbe, no pensamento federalista, à preocupação para com a ameaça à unidade nacional e à ordem social. A reforma do Estado Imperial não será mais uma tarefa vinda da sociedade, mas de elites alocadas no Estado. Enxergamos no Ato Adicional, e não na Lei de Interpretação (1839), o primeiro momento desse recuo. Ocorre que o regresso federalista era, em seus instrumentos e objetivos, bastante diferente daquele que será levado a cabo pelos centralizadores. A intenção dos federalistas com o Ato Adicional era conter os conflitos armados que apareciam no Brasil. Entretanto, para os federalistas, essa tarefa de contenção deveria ser conduzida pelo Legislativo provincial, e não pelo poder central, conforme os centralizadores pensavam - diferença significativa se pensarmos no papel do interesse provincial em cada corrente de pensamento.

Os debates acerca do Ato Adicional, que começam em $1831^{22}$, revelam a emergência da idéia de que a província possuiria negócios particulares $^{23}$, interesses particulares ${ }^{24}$, bem particular ${ }^{25}$, necessidades provinciais ${ }^{26}$, termos que denotam a presença da idéia de que a província possuía um conjunto de assuntos distintos daqueles que eram comuns a todo o Império. Ao formular a existência desses interesses provinciais, o pensamento federalista sustenta que a província deveria buscar a realização deles sem referência a motivos externos:

O que embaraça que isto sejam idéias federativas, se são idéias de justiça e ordem? [...] Não há povo que queira estar assim apertado e oprimi- 
do. Todos querem que as suas provincias tenham certos meios administrativos, certa governança que tenda a promover o bem particular da província, no que vai igualmente compreendido o bem geral do império (Lino Coutinho, sessão da Câmara dos Deputados, 17 de maio de 1831, p. 48; ênfase do autor).

Para Lino Coutinho, defensor do federalismo desde a Constituinte de Lisboa, não havia problema algum em ser tachado de federalista. Observemos, inicialmente, nos termos do autor, a idéia presente no trecho acima. Para Lino Coutinho, cada província deve dispor de "certos meios administrativos" que lhe devem permitir buscar o "bem particular da província". Ato contínuo, Lino Coutinho conclui que, nessa busca de seu bem particular, já está presente o bem geral do Império; o desenvolvimento da província contribui para o engrandecimento do Império. Podemos assinalar que a passagem do interesse provincial para o bem geral do Império é automática. No argumento do deputado, não se opera nenhum outro cálculo que não seja o da província em busca de seus objetivos. Na medida em que não existe mais um centro comum com poderes capazes de impor uniformemente uma política para todo o Império, o pensamento federalista formula a idéia de que, a partir dos interesses provinciais, poderia brotar a unidade nacional.

Na sessão de 26 de junho de 1834, estava em discussão a emenda que permitiria às Assembléias Provinciais fixar o número de seus deputados:

Sabe-se que existem entre certas províncias certa rivalidade, certo ciúme, aliás, necessários até certo ponto: esta rivalidade, este desejo de primarem umas sobre as outras, sendo razoável, pode vir a ser um princípio de progresso, sem dúvida de grande vantagem para o Brasil; mas se exorbitarem de certos limites, nós veremos que o Brasil se fracionará (Evaristo da Veiga, sessão da Câmara dos Deputados, 26 de junho de 1834; ênfase do autor).

O deputado Evaristo da Veiga acreditava que, nas províncias mais desenvolvidas, tal atribuição poderia pertencer às Assembléias Provinciais. Entretanto, nas províncias menos desenvolvidas, essa atribuição poderia dar margem a excessos. Evaristo conclui que, em face dessa distribuição desigual do desenvolvimento, deveria caber à Assembléia Geral estipular o número de deputados provinciais para cada província. O que nos parece relevante assinalar é que, na idéia de federalismo, está presente um valor que nem sequer é mencionado no argumento centralizador: a rivalidade provincial. Evaristo da Veiga, um defensor do Ato Adicional, discute o grau de liberdade que será dado 
às províncias tendo em vista que a “[...] rivalidade, este desejo de primarem umas sobre as outras, sendo razoável, pode vir a ser um princípio de progresso [...]". Na idéia de federalismo, está presente uma atribuição de valor positivo para a rivalidade provincial, a perspectiva de que a competição motiva as províncias a buscar um desenvolvimento maior. Cada província vai buscar se afirmar sobre a outra, dispor de bens que a outra não dispõe, incitando nas demais o desejo de superarem o patamar alcançado pela mais desenvolvida.

Observemos que, no conceito de federação, estava presente a idéia de um desenvolvimento desigual entre as províncias, e que tal conseqüência era inevitável. O mal de um desenvolvimento desigual era o preço a ser pago por um bem maior, o progresso advindo da competição. A meu ver, esse aspecto, já presente no trecho analisado, pode ser reforçado a partir do trecho a seguir, que se revela de grande importância:

Eu disse que as províncias devem ter toda a amplitude para se governarem; mas que era preciso que se afrouxassem o nó, e que ficassem sujeitas ao governo central por uma união doce e suportável; [...]. Eu advoguei unicamente a causa da justiça com o objeto de impedir a separação. Eu não vejo, contudo, que já se tocou neste ponto, que ele traga consigo tão graves inconvenientes, nem que dê lugar a verificar-se um quadro tão triste como o que foi apresentado pelo Sr. Cunha, acontecer-lhe-ia o mesmo que sucede a respeito dos indivíduos, alguns dos quais são mais ricose outros mais pobres. Haviam de florescer as provincias mais abundantes em produtos e ficar atrasadas aquelas que produzissem menos, as quais se verão por isso forçadas a limitar suas despesas, em proporção às suas rendas, atéchegarem à maior prosperidade (Lino Coutinho, sessão da Câmara dos Deputados, 17 de maio de 1831, p. 49; ênfase do autor).

No argumento federalista, a rivalidade provincial possui aspectos positivos. É ela que estimula as províncias a buscarem o desenvolvimento, pois cada uma não deseja ser ultrapassada pela outra. Se, por um lado, é da natureza da competição que ocorra uma distribuição desigual dos bens, por outro, tal distribuição estimularia a província menos desenvolvida a buscar os meios para atingir um padrão mais elevado de desenvolvimento. A nação é um espaço social comum às diversas províncias, no qual cada uma busca maximizar sua situação. Dessa competição vai emergir uma política nacional capaz de ligar as diversas províncias. A idéia de interesse provincial presente no concei- 
to de federalismo estava diretamente ligada ao papel desempenhado pelo interesse na sociedade.

Em 14 de novembro de 1828, escrevendo em seu jornal Aurora Fluminense, o deputado Evaristo da Veiga discorre sobre sua visão do papel da propriedade e do interesse na sociedade:

A propriedade dos homens é a fé fundamental da sociedade. Se a possessão exclusiva, que contém a propriedade, parece a princípio própria para dividir os homens, a comunicação dos bens e serviços os reúne e restabelece a única comunicação de bens conforme o interesse da reprodução. Sem propriedade de capital e lucro, não se pode conhecer senão homens selvagens, dispersos, reduzidos a uma indigência mais espantosa. O interesse é a principal causa da discórdia entre os homens; [...]. O interesse é um motivo necessário para levar o homem ao trabalho. Sem a propriedade o homem se torna um ente puramente passivo sem ação (Aurora Fluminense, 14/11/1828; ênfases do autor).

Podemos destacar, nesse trecho, duas idéias centrais: propriedade e interesse. Inicialmente, vejamos a idéia de propriedade. Evaristo associa propriedade à possessão exclusiva de um bem, o qual o indivíduo não deseja compartilhar com outro. O deputado reforça o sentido individualista, ou egoísta, da propriedade por meio da associação entre propriedade e interesse. Da mesma forma que a posse exclusiva provoca a divisão entre os homens, o interesse causa discórdia. Segundo o Dicionário Moraes, em sua edição de 1823, interesse vem a ser: "Proveito, utilidade, lucro [...] cada um trata dos seus interesses". Já interessar aponta para "[...] lucrar". Segundo Evaristo, o sentimento de egoísmo existente no interesse pode parecer algo negativo, pois a possessão exclusiva pode parecer um meio para dividir os homens. Nesse sentido, seria aparentemente um vício, ou seja, um sentimento que não traz benefício algum ao indivíduo e à coletividade. No entanto, apenas aparentemente o egoísmo é um mal. Em primeiro lugar, o interesse, no argumento de Evaristo, está associado à civilização, ao progresso. Sem o interesse, o homem se assemelha ao selvagem. É esse vício (o interesse, o egoísmo, o amor-próprio) que o leva ao aperfeiçoamento e ao desenvolvimento material. Em última instância, somos levados a concluir que é o aparecimento do interesse que move a sociedade rumo ao progresso. Em segundo lugar, essa divisão é remediada pela comunicação de bens e serviços, que nos remete à idéia de mercado como um espaço de troca. Para Evaristo, esse espaço de comunicação está dotado de uma lógica que, no final, institui uma paz entre os homens e sua luta pela posse 
exclusiva de um bem, pois é da lógica dessa comunicação funcionar segundo as necessidades de reprodução da sociedade ${ }^{27}$.

Inicialmente, assinalamos a presença, no argumento federalista, de uma analogia entre a província e o indivíduo natural. O pacto constitucional servirá a seus propósitos caso permita à província dispor de liberdade para a manifestação de seus interesses; nos termos de Ferreira França analisados anteriormente, para cuidar de sua casa; e velar pela casa implicava cuidar da segurança, justiça e prosperidade. Nesse sentido, cada província cuidaria de seus interesses da mesma maneira que o indivíduo vela pelos seus. A idéia de interesse provincial mobilizada pelos federalistas era semelhante ao uso feito por Evaristo da Veiga. Cada província buscaria sua prosperidade movida por seu interesse. Cada província cuidaria de aperfeiçoar sua casa. Esse esforço é movido por seu egoísmo, usando em seu proveito os benefícios gerados por esse empenho. O interesse geral nasce de um conflito entre os interesses. Nessa perspectiva, o interesse geral é apenas uma agregação de interesses particulares, dos quais se tira uma média, sem que esses em nenhum momento alterem seu caráter egoísta.

Estabelecido que os interesses das províncias devam estar auto-referidos e que a unidade nacional/o Estado-nação nasce da soma desses interesses, logicamente os representantes destes, ao marcarem o grau de ação do poder central, não devem permitir que este disponha de forças para alterar sua dinâmica natural. Nesse sentido, o grau de força do poder central deve ser necessariamente baixo.

Na medida em que o conceito de federação ficava associado a um arranjo constitucional que permitia às províncias a busca de seus interesses, sem que essa busca implicasse o rompimento da unidade nacional, era rechaçada a idéia de federação como uma reunião de Estados soberanos. Em 4 de julho de 1834, Souza Martins realizava um importante discurso na Câmara dos Deputados:

A palavra federação pode-se depreender por verdadeira etimologia - aliança, liga, união - concordo que não convém ao Brasil uma federação tal como a dos estados da Alemanha etc. Esta deve ter a oposição da maioria da câmara; mas não acho justo nivelar uma tal federação com as reformas que se vão agora estabelecer; estas reformas constitucionais nada mais são que dar algumas atribuições legislativas aos conselhos gerais sem dependência do poder geral; neste sentido não merece censura a federação, no sentido de dar a certas autoridades locais certas atribuições que não podem ser 
exercitadas pelo governo central (sessão da Câmara dos Deputados, 4 de julho de 1834, p. 29; ênfases do autor).

Souza Martins é um deputado favorável ao princípio federativo. Entretanto, ele recusa, para que seja aplicado ao Brasil, um determinado sentido desse termo, o de "liga, aliança e união". Observemos que os termos liga e aliança são utilizados por Hamilton para determinar o modelo oposto ao federalismo norte-americano. Souza Martins não concordava que, no Brasil, fosse aplicada a idéia de uma liga de Estados independentes. Sua adesão ao princípio federativo se dava por outros motivos. A idéia de federação, para o deputado, abarcava o princípio de se conceder às províncias maior liberdade para gerir seus assuntos. No caso em debate, a idéia de federação implicava conceder poderes mais abrangentes para as Assembléias Provinciais. O Legislativo provincial não mais seria um órgão administrativo, mas sim um órgão político.

O pensamento centralizador percebia alteração no conceito de federalismo. Não se tratava mais da união de Estados soberanos, como no modelo confederativo: "A federação que desejamos, dizem eles, não é a germânica ou a helvética ou da antiga Holanda ou da América do Norte, é apenas aquela que consiste em dar aos governos provinciais maiores atribuições para o expediente de negócios locais. E nisto insistem, senhores" (Calmon, sessão de 1o de setembro de 1832, p. 234; ênfase do autor).

À medida que se vai firmando a idéia de interesse provincial, ocorre a compreensão da inovação presente na experiência norte-americana. No debate parlamentar de 1834, emerge a compreensão de que, no conceito de federalismo, ocorreram alterações significativas em virtude da Convenção de 1787. É possível afirmar que, em 1834, a idéia de federação não envolve mais o elemento confederativo, ou seja, a União lida com seus membros como Estados soberanos aos quais ela recomenda procedimentos. O pensamento federalista abandona a idéia de que as províncias são Estados independentes: "Nos Estados Unidos há uma tendência por uniformidade de certas coisas nos diversos estados, hoje muito se fala em um código para os diversos estados da União; eles vão se aproximando à centralização quanto é possível" (Paula Araújo, sessão da Câmara dos Deputados, 25 de junho de 1834, p. 173).

Analisemos o trecho anterior tendo em vista o conceito de confederação presente até então: os membros da União estão unidos, sobretudo, com fins de defesa, mantendo cada um suas leis próprias. Segundo 
Paula Araújo, começavam a ocorrer mudanças no modelo norte-americano: a autonomia que cada membro da União dispunha para editar seus respectivos códigos estava sofrendo restrições. No debate político norte-americano, começava-se a atribuir ao poder central a tarefa de elaborar os códigos nacionais, uniformizando as diversas leis estaduais (ver Kramnick, 1993). O poder central determinava os códigos nacionais, cabendo aos poderes estaduais adequar-se a esses limites previamente estabelecidos. Portanto, a iniciativa política se invertia, cabendo agora ao poder central estabelecer os limites da ação dos Estados-membros. A compreensão desse reforço do poder central, no caso norte-americano, encontra em Evaristo da Veiga outro porta-voz:

Sigamos nossos mestres, nossos irmãos mais velhos em prudência e circunspeção; os americanos do norte existiam isolados em províncias separadas: tentaram federar-se, e a este respeito há um abuso de palavra entre nós, que nos induz a gravíssimo erro: chama-se federalista aquele que não é senão democrata, e chama-se unitário aquele que é chamado na América do Norte federalista; federalista é o que quer os laços da união, o que quer que as provincias tenham em si aquilo que lhes convém para seu bem, mas que não se desliguem uma das outras. Qual foi porém a marcha que seguiram os americanos? Estados separados trataram de reunir-se, cederam uma porção igual de seus direitos para constituírem a federação; hoje tendem a uniformizarem-se em suas instituições pela instituição da federação (sessão da Câmara dos Deputados, 26 de junho de 1834, p. 182; ênfases do autor).

Analisemos essa passagem tendo em vista os pontos discutidos anteriormente. Podemos assinalar que, para Evaristo da Veiga, o Estado norte-americano é formado a partir da reunião de Estados independentes. Entretanto, assinalava, essa situação já não correspondia à realidade naquele momento histórico. Naquela época, nos Estados Unidos, o poder central estava empenhado em uniformizar as leis, reforçando os laços comuns entre as partes. Nos Estados Unidos, federalistas eram aqueles que defendiam uma soma maior de poderes para o poder central. Fato novo se pensarmos que, na idéia de confederação, o poder central não dispunha de atribuições para agir diretamente sobre os cidadãos. Afinal, na visão dos deputados brasileiros, o que estava ocorrendo nos Estados Unidos? Vejamos um trecho de Bernardo Pereira de Vasconcelos:

Na constituição dos Estados Unidos de 1778 os estados soberanos não permitiam ao governo geral arrecadar de indivíduos a soma necessária para as despesas da União; o governo orçava as suas despesas econômi- 
cas e as províncias deviam dar a quantia necessária para fazer face a estas despesas, elas passavam a impor, a arrecadar e a remeter para o governo geral, mas o resultado foi que a maior parte das províncias se arrogarão o direito de investigar se o governo geral tinha feito o seu orçamento com excesso; e disto resultou que não mandavam os meios necessários para a União, e esta foi a principal razão por que se convocou a convenção geral de 1787, que reforçou este artigo da constituição e determinou que o governo geral em todas as ocasiões não contratasse com os estados como entidades coletivas, mas sim como indivíduos, que pudesse mandar recrutar, impor etc., enfim independentes de todos os atos por que se achava autorizado pela constituição (sessão da Câmara dos Deputados, 1ํ de julho de 1834, p. 10; ênfases do autor).

O trecho de Vasconcelos é extremamente importante. Pedimos ao leitor que observe a menção que o político mineiro faz à Constituição norte-americana de 1778*, conhecida atualmente como os Artigos da Confederação. Segundo Vasconcelos, nessa Constituição, o poder central orçava suas despesas e as províncias forneciam os recursos. Tal situação, segundo ele, levava o poder central a uma situação de dependência das províncias, porque, caso estas não concordassem com as despesas, não haveria recursos disponíveis para a ação da União. Se observarmos o conceito de confederação debatido até então, notaremos o seguinte: o governo central lida com os Estados-membros como Estados independentes, o que implicaria dizer que, em certos casos, o governo central não poderia impor medidas ao Estado-membro, mas apenas sugerir. Além disso, o governo da União não poderia agir diretamente sobre os cidadãos sem a anuência dos Estados soberanos. De acordo com Vasconcelos, o governo da União não tinha poderes para exigir que a província arcasse com a parte da despesa que lhe era devida. Em linhas gerais, o poder central, para agir, necessitava da concordância das províncias. A Convenção de 1787 assinalou uma ruptura com esse modelo. A partir de então, o poder central disporia de poderes que lhe permitiriam agir diretamente sobre os cidadãos sem necessitar da anuência das províncias. Estas deixavam de ser entidades soberanas para serem partes de um todo, do qual o poder central era o porta-voz.

\footnotetext{
* Segundo Kramnick (1993:8-9), os artigos da Confederação foram formulados em 1776 e aprovados pelo Congresso Continental em 1777. Em razão de o trecho citado mencionar 1778 , e não 1777, podemos considerar que, como se tratava da transcrição de um disurso, talvez tenha ocorrido um erro de revisão ou um lapso durante a fala. [N.A.]
} 
Portanto, em nossa análise do debate político brasileiro, podemos assinalar que a partir de 1834 ficava claro, para a elite política imperial, que nos Estados Unidos havia ocorrido um movimento que visava permitir ao poder central agir diretamente sobre os cidadãos sem lidar com as províncias, como se estas fossem Estados independentes. Nesse sentido, o conceito de federação ficava limpo dos elementos confederativos. O problema - sempre espinhoso - de que as reformas deveriam retornar às províncias para sua aprovação ou recusa, se não desaparecia de todo, ficava em segundo plano; já não aparecia como um traço necessário do conceito de federação. Com isso, as correntes federalistas passavam a centrar sua argumentação na defesa dos interesses provinciais. O pacto federativo era o espaço no qual as diversas províncias explicitavam suas demandas forjadas - forjadas internamente -, sem referência às restantes.

\section{EM DEFESA DOS INTERESSES DAS PROVÍNCIAS MAIS CIVILIZADAS}

Em 1837, era discutida a Lei de Interpretação do Ato Adicional, a qual imprimiu uma mudança nos rumos políticos do Império brasileiro. Seu conteúdo apontava claramente para um reforço do poder central em detrimento do Legislativo provincial. A Lei de Interpretação do Ato Adicional era formada por seis artigos. O primeiro e o segundo foram os mais debatidos no Senado e na Câmara. $\mathrm{O}$ art. 1ํe estabelecia que a palavra polícia, presente no art. 10을 do Ato Adicional, somente dizia respeito à polícia administrativa e não à judiciária, enquanto o art. $2 \underline{0}$ estabelecia que a Assembléia Provincial somente poderia alterar o número dos empregos criados por lei geral. Dessa maneira, a Assembléia Provincial ficava impedida de alterar a natureza e as atribuições desses empregos.

A iniciativa dos centralizadores trazia as seguintes conseqüências: em primeiro lugar, com o art. 2º, ficava vetado às Assembléias Provinciais alterarem as atribuições dos cargos. Nos termos do debate político da época, com a Lei de Interpretação, as Assembléias Provinciais não poderiam adequar as leis nacionais às necessidades das províncias. Segundo os federalistas, as leis nacionais deveriam ser adaptadas aos fins e meios estabelecidos pela Assembléia Provincial, o órgão mais próximo à realidade provincial. Em segundo lugar, com o art. 1으, distinguia-se a polícia administrativa da polícia judiciária, sendo esta subordinada ao poder central ${ }^{28}$. A polícia judiciária ficava inteiramente subordinada ao poder central. Conforme os adversários da Lei de 
Interpretação costumavam repetir, o ministro da Justiça controlava da nomeação do presidente de relação até o carcereiro.

As correntes federalistas criticaram o conteúdo centralizador da lei, contrário aos interesses provinciais. Segundo o senador Alencar, a transferência de atribuições para a Assembléia Geral não seria apropriada, pois esta estaria mais ocupada com "o todo da nação sem capacidade para os negócios peculiares das províncias" (sessão do Senado, 29 de julho de 1839). O órgão encarregado de cuidar dos negócios peculiares das províncias deveria ser o Legislativo provincial. Vejamos o argumento do ex-ministro da Justiça e regente e, naquele momento, senador, Diogo Antônio Feijó:

Na verdade, já se mostrou que a polícia interna é essencial a toda corporação, desde a família até a associação geral, que dela depende a existência e a conservação da mesma sociedade; sendo isto assim, como é que, podendo o chefe de família regular a sua economia doméstica, o município a sua economia municipal, o mestre a economia de sua aula, na qual regula o serviço e os castigos correcionais etc., as câmaras legislativas da mesma sorte, como então se quer negar este direito às províncias? (sessão do Senado, 26 de julho de 1839, p. 371; ênfase do autor).

Segundo Feijó, o cidadão ativo, para o bom funcionamento da casa, deve controlar a economia doméstica. De acordo com o Dicionário Moraes (1844), "economia" significava: "O regime ou governo dos bens ou da casa de cada um. Economia política: ciência que ensina a conhecer as riquezas naturais e industriais de um país e os modos de aproveitar e acrescentar". Da mesma maneira, para o bom funcionamento e desenvolvimento da província, o Legislativo provincial deveria controlar a polícia judiciária.

O argumento de Feijó, ao mobilizar a idéia do controle sobre a economia doméstica, confere uma dimensão extremamente ampla à discussão acerca da polícia judiciária. Desse modo, manifesta-se, em seu argumento, um dos traços fundamentais do conceito de federalismo: a idéia de que a província deve lidar com seus assuntos da mesma forma que o cidadão ativo lida com a casa (ver Mattos, 1994). A justificativa para a liberdade provincial busca sua lógica na esfera privada e, mais especificamente, em uma determinada idéia de indivíduo. O cidadão ativo que melhor controla os recursos de sua casa obtém, na competição entre os demais, uma posição mais vantajosa. A província, ou melhor, o Legislativo provincial, eleito pelos cidadãos ativos, regula a po- 
lícia judiciária tendo em vista a melhor maneira de aproveitar os recursos naturais e sociais da província. Nesse sentido, o federalismo é um arranjo político que permite às províncias a busca da melhor forma de aproveitar seus recursos sociais e naturais, de tal modo que, na competição entre as demais unidades da federação, a localidade consiga predominar. A organização retira sua lógica do cidadão ativo e da competição entre esses cidadãos.

O argumento centralizador apontava para os conflitos de interpretação desencadeados a partir da promulgação do Ato Adicional. Segundo Paulino José Soares de Souza, deputado geral e ex-presidente da província do Rio de Janeiro, a permissão para que a Assembléia Provincial Legislasse sobre a criação e a supressão de empregos provinciais teria gerado leis provinciais que alteraram atribuições estabelecidas por leis nacionais. Como Paulino escreveu no Ensaio, à Assembléia Geral competia fazer os códigos civil, de processos etc.; às assembléias provinciais, criar os empregos necessários e marcar-lhes a atribuição como se fosse possível separar uma coisa da outra (ver Souza, 1997:373).

O pensamento federalista reconhecia esses conflitos, mas apontava para um aspecto positivo contido no Ato Adicional. Vejamos a defesa que Teófilo Ottoni realiza do Ato Adicional:

Apontar-se-há um outro exemplo de leis provinciais absurdas; mas são esses casos exceções de regra geral; e absurdos, leis mancas também têm saído desta casa, têm sido sancionadas pelo poder moderador, e muitas vezes no ano seguinte nós vemos na necessidade de reformá-las. Talvez que pudesse apresentar como prova o que os nobres deputados dizem a respeito do código do processo; não o faço, porém, porque também creio que com ele não tem aparecido esses males que se têm apregoado; pelo menos não os vejo na província donde sou filho, mas peço licença à câmara para poder dizer que talvez nasça isso de ser a província de Minas uma das mais ilustradas, sem querer deslustrar as 17 co-irmãs. Em Minas posso assegurar que a administração de justiça tem melhorado com os códigos: citarei para exemplo os crimes contra a propriedade, avultavam muito mais do que atualmente. Em alguns municípios tem sucedido muitas vezes, havendo neles autoridades ativas que nem um só processo se apresenta para se submeter à consideração dos jurados: as coisas têm melhorado, e por conseguinte temos progredido. Ora, o que sucede em Minas talvez suceda na Bahia e em muitas outras importantes provincias que estão em circunstâncias de exercer todos os direitos que o Ato Adicional confere. 
Sr. Presidente, se há uma província em que os jurados não podem ainda ter lugar; e noutra em vez de guardas nacionais mais quadram as antigas milícias no maior número e nas mais importantes; a civilização tem feito muitos progressos, e não acho justo que a maioria sofra quebra de prerrogativas, porque uma minoria insignificante pode abusar, ou não tirar vantagens que elas concedem (sessão da Câmara dos Deputados, 12 de junho de 1839, p. 383; ênfases do autor).

Inicialmente, observemos a referência à promulgação de leis provinciais absurdas. Esse era um dos pontos mais mencionados pelos defensores da Lei de Interpretação. Segundo Paulino José Soares de Souza, em algumas províncias, o Legislativo provincial extinguiu cargos previstos no Código do Processo transferindo suas atribuições para outros cargos, ou simplesmente suprimind o o cargo, mas sem definir que cargos herdariam suas tarefas. Teófilo Ottoni reconhecia que tais exemplos estavam ocorrendo, mas destacava que o Legislativo geral ocasionalmente aprovava leis para posteriormente reformá-las. Em síntese, no Legislativo geral, também eram produzidas leis absurdas. Em seguida, Teófilo Ottoni argumentava que, em Minas Gerais, desde a promulgação do Ato Adicional a administração da Justiça havia melhorado. O político mineiro não mencionava que a produção legislativa provincial de Minas fosse caracterizada por leis incompatíveis com as leis nacionais. Segundo ele, o motivo pelo qual isso se dava residia no fato de Minas ser uma das províncias mais ilustradas. Um pouco mais adiante, seu argumento indicava que o progressivo desenvolvimento da civilização no Brasil contribuiria para que cada vez um número menor de leis absurdas fossem promulgadas. Estabelecendo essas premissas, Ottoni conclui que a supressão do Ato Adicional não poderia ser realizada porque, nas províncias mais civilizadas, não eram encontrados motivos suficientes para cancelar a descentralização.

Podemos formular a seguinte pergunta: será que Ottoni imaginava que a maior parte das províncias no Brasil possuía o mesmo nível de civilização presente em Minas Gerais e na Bahia? Podemos afirmar que o deputado eleito pela província de Minas não considerava que a difusão da civilização na sociedade brasileira fosse homogênea. A imagem mais comum no pensamento político brasileiro, seja nos centralizadores, seja nos federalistas, foi a de uma sociedade com ilhas de civilização cercadas por um vasto sertão. Mesmo nas províncias mais ricas, a presença da civilização estava restrita às cidades mais populosas. $\mathrm{O}$ uso que Ottoni faz do termo maioria para se referir às províncias que 
não deveriam sofrer com a quebra da descentralização prevista no Ato nos parece mais um recurso parlamentar para angariar apoio do que um julgamento acerca da sociedade brasileira.

Portanto, podemos formular a seguinte conclusão: no argumento de Ottoni, não havia motivos que levassem ao cancelamento do Ato Adicional. Tal posição decorria do lugar de onde Ottoni analisava o funcionamento do Ato Adicional, ou seja, de uma das províncias mais civilizadas. Em nenhum momento de seu argumento, é introduzida a idéia de que o Ato Adicional deveria ser mantido tendo em vista todo o Império, formado por partes heterogêneas, por províncias marcadas pela civilização ou pela barbárie. Em resumo, Ottoni pensava o arranjo político que costurava o pacto entre as diversas partes que compunham a União com base nas províncias mais civilizadas e seus interesses.

A mesma perspectiva estava presente em Tavares Bastos, em sua crítica às leis centralizadoras e na defesa do Ato Adicional:

Não hesitamos em condenar a organização policial e judiciária da lei de 3 de dezembro; mas também não reputamos tão elevada superfície de nossa civilização, que a todo o país se possa aplicar o princípio da polícia eletiva. Se, por um lado, fora inconveniente estender este belo princípio às solidões do Amazonas è̀s florestas de Goiás e Mato Grosso,é, por outro lado, injustíssimo privar do gozo dessa liberdade as províncias superiores em civilização. Por isso condenamos a uniformidade nas instituições secundárias do governo dos povos (1937:173; ênfase do autor).

Observemos o início do trecho. Nele, Tavares Bastos criticava o mecanismo descentralizador presente no Código do Processo: tornar elegível a partir do município os principais cargos do aparelho Judiciário. O motivo pelo qual Tavares Bastos criticava esse fato residia na difusão desigual da civilização no Brasil. Sendo um país heterogêneo, as precondições civilizatórias para que esse mecanismo fosse aplicado não estavam homogeneamente espalhadas pelo território brasileiro. Com a descentralização prevista no Código do Processo, eclodiram diversas revoltas que mobilizaram os setores subalternos da sociedade. Nestes, a força do interesse era fraca em virtude de sua inserção marginal na sociedade brasileira. Entretanto, devemos assinalar o seguinte: essa idéia, a difusão desigual da civilização na sociedade brasileira, é utilizada também para efetuar a crítica ao mecanismo centralizador - a lei de 3 de dezembro. Da mesma maneira que os federalistas aplicaram in- 
distintamente o princípio descentralizador em todo o país, os centralizadores efetuaram esse mesmo molde; aplicaram uniformemente a concentração de atribuições nas mãos do poder central.

Em seguida, o argumento de Tavares Bastos opera uma passagem decisiva. A centralização aplicou uniformemente um princípio sacrificando as províncias mais civilizadas. Em sua perspectiva, está presente a idéia de que os interesses das províncias mais civilizadas não podem ser prejudicados pela necessidade de coesão entre as diversas partes que compõem o Império brasileiro. Para Tavares Bastos, onde for possível que o interesse fecunde a sociedade sem levantar a ameaça das rebeliões, a descentralização deve ser adotada; porém, nas regiões nas quais esse interesse for ameaçado, a descentralização deve ser contida. O instrumento mais capaz para realizar esse cálculo vem a ser o Legislativo provincial. Isso porque o guia de sua ação não serão os interesses vagos e vazios do todo, da nação, mas sim os interesses provinciais. As províncias mais civilizadas não deveriam perder a liberdade - prevista no Ato Adicional - de controlar a polícia judiciária porque outras, menos civilizadas, haviam abusado dessa prerrogativa. Ou seja, no argumento de Ottoni, as províncias mais civilizadas não deveriam abrir mão da descentralização em favor das províncias menos civilizadas.

Devemos deslocar para dentro do argumento de Ottoni e de Tavares Bastos o conceito de federalismo a fim de precisarmos seu sentido político. O conceito de federalismo envolve a idéia de que a província possui interesses que lhe dizem respeito exclusivamente. O pacto federativo deve conceder liberdade às províncias para marcar os fins e os meios a serem atingidos. No conceito de federalismo, essa liberdade é fundamental, pois é ela que assegura que esse interesse provincial se manifeste plenamente. O poder central não deve, para os federalistas, introduzir valores estranhos à província. A prosperidade comum, segundo os federalistas, nasce da busca de cada província em satisfazer suas políticas. Nesse sentido, para Ottoni e Tavares Bastos, as províncias mais civilizadas não devem restringir sua liberdade provincial em nome de valores que dizem respeito a uma realidade estranha a seus interesses. Em seu argumento, as províncias menos desenvolvidas desempenham o mesmo papel descrito por Lino Coutinho anteriormente: da mesma maneira que alguns indivíduos não são bem-sucedidos na realização de seus interesses, o pacto federativo deve permitir que as províncias mais capazes se imponham. Um dos valores que reagem ao arranjo descentralizador é a competição, bem como sua inevitável 
desigualdade. Nesse sentido, considero que a compreensão do debate entre centralizadores e federalistas no século XIX no Brasil passa, necessariamente, pela compreensão do conceito de interesse provincial e da maneira pela qual essas correntes avaliaram esse conceito.

\section{CONCLUSÃO}

Neste artigo, busquei identificar o conteúdo da idéia de interesse provincial e como este interage com a idéia da formação do Estado-nação entre centralizadores e federalistas. Assinalar o vínculo entre o interesse de grupos sociais e de províncias no debate entre centralizadores e federalistas é um elemento de grande importância ${ }^{29}$. O que falta conhecer é como cada corrente política avaliou o papel desses interesses na construção do Estado-nação.

No caminho percorrido, podemos assinalar que, para os federalistas, é a partir dos interesses, característica do cidadão ativo, e de sua dinâmica que o Estado-nação deve ser montado. Esse cidadão ativo se encontra mais presente nas províncias mais civilizadas. Nesse sentido, o pacto federativo deve partir das províncias mais civilizadas para o centro. O movimento dos atores políticos - que mais tarde vão se opor à política centralizadora - caminhava no sentido de adequar a descentralização às regiões mais civilizadas. Esse movimento político objetivo, como assinalava Alves Branco em seu relatório de ministro da Justiça, era fazer recuar esses chefes políticos turbulentos. Como fazê-lo?

A corrente federalista operou com o Ato Adicional uma redefinição politicamente significativa na idéia de federalismo. O debate político em torno do Código do Processo apresentou a idéia de federalismo como uma política que deveria descentralizar o poder, colocando-o mais próximo ao cidadão. O Estado colonial era visto como uma máquina política estranha ao cidadão ativo. Nesse sentido, descentralizar o poder envolvia despertar o cidadão para a importância de sua participação nos assuntos públicos de tal maneira que seus interesses fossem combinados com o bem público.

Com o Ato Adicional, essa dimensão é posta em segundo plano. Para os federalistas, a emergência dos conflitos armados, com sua inevitável malta turbulenta, a partir da promulgação do Código do Processo, exige uma redefinição da idéia de federalismo. $O$ ator principal do federalismo não será mais o cidadão ativo, localizado nos municípios, mas o 
Legislativo provincial. As elites políticas situadas no Legislativo vão comandar a disseminação do poder pela sociedade.

A ação desse Legislativo provincial apontou para a direção do esvaziamento das figuras centrais do Código do Processo: o juiz de paz e o júri. As atribuições destes são esvaziadas em favor do juiz de direito, que com o Ato Adicional passa a ser controlado por esse Legislativo. A própria Câmara Municipal passa a ser controlada pelo Legislativo provincial, com a criação da figura do prefeito. Se pensarmos que essa ação de esvaziamento não era coordenada, podemos supor, a partir de seu sentido inicial, que atingiria os demais cargos escolhidos no município - o promotor e o juiz municipal.

Ao mesmo tempo que os liberais moderados operavam essa redefinição do conceito de federalismo, outro movimento intelectual era realizado: a idéia de federação era apresentada de maneira distinta da idéia de confederação. No começo da década de 1830, as inovações operadas no contexto político norte-americano eram percebidas no debate político brasileiro. $\mathrm{O}$ conceito de federalismo não envolvia a noção de que os Estados-membros do pacto fossem soberanos. Em contrapartida, emerge como aspecto central a idéia de que as províncias possuíam negócios particulares, interesses, necessidades provinciais. Para que tais assuntos fossem atendidos, era necessário que o Legislativo provincial fosse o órgão encarregado de adaptar as leis nacionais à realidade local. Na formulação dessa perspectiva, a corrente federalista mobilizava a idéia de interesse: as províncias - tal como o cidadão ativo no controle da casa - velava por seus interesses de tal maneira que estes eram forjados internamente, sem referência ao interesse da nação. Esse era o resultado do conflito entre os vários interesses provinciais. $\mathrm{O}$ conflito deveria ocorrer dentro de limites pacíficos, mas era essa dinâmica conflituosa que impulsionava o desenvolvimento nacional e impedia a possibilidade de arbítrio do poder central.

Busquei destacar que as correntes federalistas favoráveis ao Ato Adicional empreenderam uma resistência às leis centralizadoras com base nas idéias acima delineadas. $O$ pensamento federalista reconhecia que o Ato Adicional havia permitido certas leis absurdas; algumas das medidas tomadas por legislativos provinciais contrariavam as leis nacionais. No entanto, tal fato não justificava que fosse tolhida a autonomia das províncias mais civilizadas. Nestas, em razão do maior nível de civilização existente, a promulgação das leis absurdas não se manifesta- 
va da mesma forma que nas províncias menos civilizadas. Para os federalistas, o pacto federativo era pensado a partir do interesse das províncias mais civilizadas. A idéia de uma ação que procurasse intencionalmente regular esses interesses a partir de valores referidos à idéia de Estado-nação surge aos federalistas como uma via arbitrária e contrária aos interesses provinciais.

(Recebido para publicação em junho de 2007) (Versão definitiva em novembro de2008)

\section{NOTAS}

1. Ver, por exemplo, Torres (1961).

2. Idéia de conceito pensada a partir de Koselleck (2006).

3. Ver Plano e Greenberg (1965), Riker (1973), Levi (1986), Bulpitt (1996) e Grant (1996).

4. Sobre o processo histórico norte-americano que compreende dos Artigos da Confederação até a Convenção da Filadélfia, ver Kramnick (1993) e Storing (1981).

5. A historiografia mais recente tem ressaltado que a idéia de que, com a Convenção da Filadélfia, o poder central passa a dominar as identidades regionais é um equívoco. A própria persistência da escravidão nos estados do sul aponta para a força política dos Estados e para a limitação dos poderes do governo nacional. O reforço do poder central e a mudança do modelo confederativo para federativo constituíram um lento processo histórico que começou em 1787. Ver Greene (2006a; 2006b), Pamplona (2003, especialmente o capítulo 3) e Grant (1996).

6. As citações foram retiradas do tomo I, que foi publicado em 1832. A inovação norte-americana ainda não estava inteiramente clara para o debate político francês. $\mathrm{O}$ dicionário da Academia Francesa, em sua edição de 1832-1835, ainda definia "federal" utilizando a referência da confederação: Féderal qui rapport à une conféderation. Por sua vez, o termo "federativo" estava ainda mais associado a confederação: Fédératif. De l'association politique de plusieurs États, unis entre eux para une aliance général, et soumis en certains cas à des déliberations communes, mais dont chacun est regi par ses lois particulières.

7. Emenda apresentada pelo deputado Antonio Ferreira França, em 17 de setembro de 1823.

8. Sobre o federalismo pernambucano, ver Mello (2004).

9. "A assembléia declara, deste modo, que jamais se adotaram planos financeiros que retardem como até agora a marcha do engrandecimento de cada uma das províncias: diz mais, que os empregados públicos serão em regra tirados dos próprios cidadãos: estes mais ligados, mais interessados pelo solo onde exercem jurisdição, poiséseu país natal; serão mais pontuais, mais ativos, e vigilantes não cansarão de promover a pública prosperida- 


\section{Ivo Coser}

de" (Montezuma, sessão da Câmara dos Deputados, 17 de setembro de 1823, p. 155; ênfase do autor).

10. Uma análise extremamente esclarecedora do funcionamento do juiz de paz, com a promulgação do Código do Processo, pode ser encontrada em Flory (1986) e em Velasco (2002).

11. "Finalmente, pode-se estabelecer como regra, apesar de uma ou outra exceção, que todo poder, cuja responsabilidade está longe do foco das suas ações, é infalivelmente mais, ou menos, arbitrário e por conseqüência sempre pesado aos Povos. Não será assim com o regime federativo. As autoridades escolhidas pelo mesmo Estado onde tem de exercer as suas funções vem a responsabilidade iminente, como Dâmocles tinha a espada que o devia punir pendente por um fio sobre a sua cabeça" (Astro de Minas, 28/6/1832).

12. Sobre a vida de Evaristo da Veiga, ver Sousa (1988a).

13. Sobre o arranjo institucional do Ato Adicional, ver Carvalho (1998) e Dolhnikoff (2005).

14. Ver parecer sobre a Reforma da Constituição apud Pinto (1983:449-470).

15. Ver emendas aprovadas pelo Senado ao projeto da Câmara dos Deputados, Pinto (1983:476-477).

16. O projeto da chamada Constituição de Pouso Alegre encontra-se em Sousa (1988b).

17. Ver Alves Branco, relatório de ministro da Justiça (1835:18-19), ou Limpo de Abreu, relatório de ministro da Justiça (1836:30-31).

18. Ver Alves Branco, relatório de ministro da Justiça (1834:22).

19. Ver Limpo de Abreu, relatório de ministro da Justiça (1836:34), e Alves Branco, relatório de ministro da Justiça (1834:23).

20. Efetuei uma análise dos sentidos do termo civilização presentes no debate entre centralizadores e federalistas no capítulo 5 de minha tese de doutorado. Nesse capítulo, proponho o conceito de civilização/sertão como um instrumento de análise para a reflexão política do século XIX. Ferreira (1999) efetuou uma análise relevante do tema civilização no debate entre Tavares Bastos e Visconde do Uruguai, especialmente nas pp. 125-144.

21. Ver Fernandes (1975, especialmente os três primeiros capítulos) e Werneck Vianna $(1991 ; 1996 ; 1997)$.

22. A primeira moção apresentada para as reformas constitucionais que viriam a ser o Ato Adicional foi apresentada em 6 de maio de 1831. Ver Pinto (1983:443).

23. Ver Anais da Câmara dos Deputados, sessão de 17 de maio de 1831, p. 48.

24. Ver Anais da Câmara dos Deputados, sessão de 17 de maio de 1831, p. 47.

25. Ver Anais da Câmara dos Deputados, sessão de 17 de maio de 1831, p. 48.

26. Ver Marinho (1978:20).

27. Podemos perguntar: de onde Evaristo retirou tais idéias? Muito provavelmente de Adam Smith, se não diretamente, por meio de algumas das passagens difundidas por um contemporâneo seu, José da Silva Lisboa. O ponto que, a meu ver, deve ser destacado na passagem anterior, e que justifica que se utilize como referência o pensamento de Adam Smith, reside na relação entre um aparente vício e o desenvolvimento da sociedade. Albert Hirschman (1979) destaca, em seu trabalho, o fato de que 
uma das principais contribuições de Adam Smith, no campo das idéias, foi tornar paixões anteriormente consideradas vício em qualidades que levam à melhoria das condições sociais. E o fez, em primeiro lugar, substituindo a expressão vícios privados, usada por Bernard Mandeville em The Fable of the Bees, por expressões quase neutras como vantagem ou interesse. Em segundo, por meio de sua obra mais importante, $A$ Riqueza das Nações, Adam Smith apresenta os homens agindo exclusivamente no "desejo de melhorar suas condições"; é o interesse, ou seja, uma motivação econômica que alimenta a sociedade. Nas palavras de Hirschman (ibidem:103), “[...] os impulsos não econômicos, por mais poderosos que sejam, se alimentam dos impulsos econômicos e só fazem reforçá-los, estando eles assim privados de sua existência independente anterior". Não se trata de imputar a Evaristo uma teoria complexa sobre os sentimentos morais, como está presente em Adam Smith, mas sim de apontar a presença da idéia de que são os interesses egoístas do indivíduo por seu bem-estar material que movem a sociedade em direção ao progresso.

28. A polícia judiciária dizia respeito à repressão e à prevenção de delitos, enquanto a polícia administrativa tratava da salubridade dos lugares, estradas, feiras, mercados públicos etc. Ver a definição de Lopes Gama, sessão do Senado, 26 de julho de 1839, p. 381.

29. Aspecto estabelecido por Lenharo (1993), Fragoso (1992) e Mattos (1994; 1999; 2005).

\section{REFERÊNCIAS BIBLIOGRÁFICAS}

ALMEIDA JÚNIOR, João Mendes de. (1920), O Processo Criminal Brazileiro (3a ed.). Rio de Janeiro, Typographia Baptista.

BAJER, Paula. (2002), Processo Penal e Cidadania. Rio de Janeiro, Zahar.

BASTOS, Aureliano Candido Tavares. (1937) [1870], A Província (2a ed.). São Paulo, Nacional.

BULPITT, Jim. (1996), "Federalism", in I. McLean e A. McMillan, The Concise Oxford Dictionary of Politics. London, Oxford University Press.

CARVALHO, José Murilo de. (1998), “Federalismo e Centralização no Império Brasileiro: História e Argumento", in Pontos e Bordados. Belo Horizonte, Editora UFMG.

DOLHNIKOFF, Miriam. (2005), O Pacto Imperial: Origens do Federalismo no Brasil do Século XIX. São Paulo, Globo.

FERNANDES, Florestan. (1975), "As Origens da Revolução Burguesa", in A Revolução Burguesa no Brasil. Rio de Janeiro, Zahar.

FERREIRA, Gabriela Nunes. (1999), Centralização e Descentralização no Império: O Debate entre Tavares Bastos e Visconde de Uruguai. São Paulo, Editora 34.

FLORY, Thomas. (1986), El Juez de Paz y el Jurado en Brasil Imperial. México, Fondo de Cultura Económica. 


\section{Ivo Coser}

FRAGOSO, João. (1992), Homens de Grossa Aventura: Acumulação e Hierarquia na Praça Mercantil do Rio de Janeiro (1790-1830). Rio de Janeiro, Arquivo Nacional.

GRANT, Wyn. (1996), “Confederation”, in I. McLean e A. McMillan, The Concise Oxford Dictionary of Politics. London, Oxford University Press.

GREENE, Jack P. (2006a), “Reformulando a Identidade Inglesa na América Britânica Colonial: Adaptação Cultural e Experiência Provincial na Construção de Identidades Corporativas". Almanack Braziliense, no 4 .

. (2006b), "State and National Identities in the Era of the American Revolution", in D. H. Doyle e M. A. Pamplona (eds.), Nationalism in the New World. Athens, The University of Georgia Press.

HIRSCHMAN, Albert. (1979), As Paixões e os Interesses. São Paulo, Paz e Terra.

JASMIN, Marcelo. (2000), “Interesse Bem Compreendido e Virtude em A Democracia na América", in N. Bignotto (org.), Pensar a República. Belo Horizonte, Editora UFMG.

KOSELLECK, Reinhart. (2006), Futuro Passado: Contribuição à Semântica dos Tempos Históricos. Rio de Janeiro, Contraponto/Ed. PUC-Rio.

KRAMNICK, Isaac. (1993), "Apresentação", in J. Madison, A. Hamilton e J. Jay, Os Artigos Federalistas, 1787-1788. Rio de Janeiro, Nova Fronteira.

LENHARO, Alcir. (1993), As Tropas de Moderação (2a ed.). Rio de Janeiro, Secretaria Municipal de Cultura e Turismo.

LEVI, Lucio. (1986), “Federalismo”, in N. Bobbio (org.), Dicionário de Política. Brasília, Ed. $\mathrm{UnB}$.

MADISON, James, HAMILTON, Alexander e JAY, John. (1993), Os Artigos Federalistas, 1787-1788. Rio de Janeiro, Nova Fronteira.

MARINHO, José Antonio. (1978), História da Revolução de 1842. Brasília, Ed. Senado/UnB.

MATTOS, Ilmar Rohloff de. (1994), O Tempo Saquarema: A Formação do Estado Imperial (3a ed.). Rio de Janeiro, Access.

(1999), “O Lavrador e o Construtor: O Visconde de Uruguai e a Construção do Estado Imperial”, in M. E. Prado (org.), O Estado como Vocação: Idéias e Práticas Políticas no Brasil Oitocentista. Rio de Janeiro, Access.

. (2005), “Construtores e Herdeiros: A Trama dos Interesses na Construção da Unidade Política". Almanack Braziliense, no 15.

MELLO, Evaldo Cabral de. (2004), A Outra Independência: O Federalismo Pernambucano de 1817 a 1824. São Paulo, Editora 34.

PAMPLONA, Marco A. (2003), "O Republicanismo Norte-Americano", in Revoltas, Repúblicas e Cidadania. Rio de Janeiro, Record.

PINTO, Antonio Pereira (org.). (1983) [1875], Lei de 12 de Outubro de 1832. Ato Adicional. Lei de Interpretação. Moções Parlamentares que Deram Origem à Promulgação das Reformas Constitucionais, in Reforma Eleitoral. Brasília, Ed. UnB.

PLANO, Jack e GREENBERG, Milton. (1965), "The Federal Union and Territories", in American Political Dictionary. New York, Holt, Rinehart and Winston. 
RIKER, William. (1973), “Federalism”, in Governmental Institutions and Processes. Menlo Park, Addison-Wesley Publishing Company.

SOUSA, Octávio Tarquínio de. (1988a), Evaristo da Veiga. Belo Horizonte, Itatiaia. . (1988b), Três Golpes de Estado. Belo Horizonte, Itatiaia.

SOUZA, Paulino José Soares de Souza (Visconde do Uruguai). (1997) [1862], Ensaio sobre o Direito Administrativo. Brasília, Ministério da Justiça.

STORING, Herbert J. (1981), What the Anti-Federalists Were For. Chicago, University of Chicago Press.

TOCQUEVILLE, Alexis de. (1977), A Democracia na América. Belo Horizonte, Itatiaia.

TORRES, João Camilo de Oliveira. (1961), A Formação do Federalismo no Brasil. São Paulo, Companhia Editora Nacional.

VELASCO, Ivan. (2002), As Seduções da Ordem: Violência, Criminalidade e Administração da Justiça de Minas Gerais, Século XIX. Tese de doutorado, IUPERJ, Rio de Janeiro.

WERNECK VIANNA, Luiz. (1991), “Americanistas e Iberistas: A Polêmica de Oliveira Vianna com Tavares Bastos". DADOS, vol. 34, no 2, pp. 145-189.

. (1996), “Caminhos e Descaminhos da Revolução Passiva à Brasileira”. DADOS, vol. 39, no 3, pp. 377-392.

(1997), A Revolução Passiva: Iberismo e Americanismo no Brasil. Rio de Janeiro, Revan. 
Ivo Coser

\section{FONTES CONSULTADAS}

Anais da Câmara dos Deputados: 1823, 1827, 1831, 1833, 1834, 1837, 1839, 1840 e 1841.

Anais do Senado: 1831, 1832, 1834, 1839 e 1840.

Código do Processo de 1832. Rio de Janeiro, Typographia Nacional, 1874.

Coleção das Leis do Império do Brasil. Rio de Janeiro, Typographia Nacional, 1827, 1832 e 1834.

Relatórios de Ministro da Justiça: 1832, 1833, 1834, 1835 e 1836.

Jornais: Aurora Fluminense; A Malagueta; Nova Luz Brasileira; Astro de Minas.

SILVA, Antonio de Moraes. Dicionário da Língua Portugueza, edições de 1813, 1831 e 1844. 


\section{ABSTRACT \\ The Concept of Federalism and the Notion of Interest in $19^{\text {th }}$ Century Brazil}

This article analyzes the formation of the concept of Federalism in $19^{\text {th }}$ century Brazilian political debate. We seek to understand the transition from the concept of Confederation to that of Federalism and the political values that came to be associated with the latter. Based on the methodology of Conceptual History formulated by Reinhart Koselleck, we focus on the continuities and breaks in the issue of decentralization. Analyzing $19^{\text {th }}$ century newspapers and Parliamentary debates, we contend that the notion of Provincial interest is a key aspect for understanding the Federalist thinking formulated in the first half of the $19^{\text {th }}$ century.

Key words: federalism; confederation; Brazilian political thinking; nation-building; Judiciary

\section{RÉSUMÉ}

Le Concept de Fédéralisme et l'Idée d'Intérêt dans le Brésil du XIX Siècle

Dans cet article, on cherche à comprendre la formation du concept de fédéralisme dans le domaine politique brésilien du XIXe siècle. $C^{\prime}$ est-à-dire, le passage du concept de confédération vers celui de fédéralisme ainsi que les valeurs politiques qui y seront associés. Suivant la méthodologie de l'Histoire des Concepts proposée par Reinhart Koselleck, on a essayé d'observer les continuités et les discontinuités par rapport au sujet de la décentralisation. D'après l'analyse des journaux et des débats parlementaires de l'époque, on perçoit que l'idée d'intérêt provincial est un aspect fondamental pour comprendre la pensée fédéraliste diffusée pendant la première moitié du XIX ${ }^{\mathrm{e}}$ siècle.

Mots-clé: fédéralisme; Confédération; pensée politique brésilienne; construction de l'État nation; pouvoir judiciaire 